\title{
ОДНОСТАДИЙНАЯ ОБРАБОТКА ПЛОДОВЫХ ОБОЛОЧЕК ОВСА ДЛЯ ПОЛУЧЕНИЯ БИОЭТАНОЛА - ПРЕКУРСОРА ЭТИЛЕНА
}

\author{
О.В. Байбакова, Е.А. Скиба, И.Н. Павлов, В.В. Будаева, Ю.А. Крюков, \\ В.Н. Золотухин, Е.И. Кащеева, Ю.А. Гисматулина, Г.Ф. Миронова, \\ Е.К. Гладышева, А.А. Корчагина, Г.В. Сакович
}

В данной работе приведены результаты масштабирования процесса получения биоэтанола в производственных условиях из плодовых оболочек овса, обработанных в одну стадию разбавленным раствором азотной кислоты. На основании лабораторных исследований разработана и предложена аппаратурно-технологическая схема получения биоэтанола из недревесного целлюлозосодержащего сырья в условиях опытно-промышленного производства. Разработанная технология получения биоэтанола из продукта азотнокислой обработки плодовых оболочек овса внедрена в производственных условиях ИПХЭТ СО РАН. Полученный субстрат (продукт азотнокислой обработки) характеризуется высоким содержанием гидролизуемых компонентов $-88,4 \pm 0,3$ \%. В аппарате емкостью 63 л в водной среде был маситабирован процесс совмещенного осахаривания и сбраживания при использовании ферментных препаратов «Целлолюкс-А» и "Брюзайм BGX», а также промышленного штамма дрожжей Saccharomyces cerevisiae ВКПМ Y-1693. Получен биоэтанол с выходом 17,9 дал из 1 m плодовых оболочек овса. Методом газожидкостной хроматографии выявлено, что опытный образец биоэтанола характеризуется крайне низкой концентрацией метанола. Установлено, что после ректифрикации опытный образец биоэтанола по массовой концентрации альдегидов, эфииров соответствует спирту высшей очистки из пищевого сырья.

Ключевые слова: биоэтанол, плодовые оболочки овса, азотнокислая обработка, производственные условия, осахаривание, ферментные препараты, сбраживание, Saccharomyces cerevisiae Y-1693.

\section{ВВЕДЕНИЕ}

Такие источники лигноцеллюлозной биомассы, как отходы сельского хозяйства, являются перспективным сырьем для процесса производства биоэтанола. Среди сельскохозяйственных отходов одними из самых перспективных могут стать плодовые оболочки овса (ПОО). По данным Росстата валовый сбор овса в России в 2015-2017 гг. составляет в среднем 4,8-5,5 млн. т в год, что соответствует 1,3-1,5 млн. т ПОО, кроме того, данный вид сырья распространен в глобальном масштабе. Массовая доля целлюлозы в них составляет $35-45 \%$, что позволяет рассматривать ПОО именно как источник целлюлозы.

С точки зрения экономики, производство целлюлозного биоэтанола связано с несколькими ключевыми технологическими проблемами. Идентификация узких мест, которые ограничивают масштабирование процесса получения биоэтанола с высоким выходом в производственных условиях, является фундаментальной задачей современной науки. Плюсом использования ПОО является их готовность к дальнейшей технологической переработке: уже проведены трудоёмкие стадии сбора, транспортировки и очистки сырья, что включено в производственный цикл зерна, кроме того, ПОО не требует измельчения. Существует необходимость поиска экономически эфрфективных режимов предварительной обработки лигноцеллюлозной биомассы, позволяющих получать субстраты с высокой реакционной способностью к осахариванию и биоэтанол с высоким выходом [1-2].

Совмещенный процесс осахаривания и сбраживания рассматривается как эффрективная стратегия для снижения издержек производства, увеличения концентрации биоэтанола и сокращения технологических стадий из-за исключения длительной стадии осахаривания.

При совмещенном осахаривании и сбраживании повышается скорость осахаривания и выход биоэтанола за счет уменьшения ингибирования конечным продуктом $\beta$-глюкозидазы на стадии осахаривания, так как при внесении продуцентов биоэтанола редуцирующие вещества начинают отводиться из системы и расходоваться на синтез биоэтанола 


\section{ОДНОСТАДИЙНАЯ ОБРАБОТКА ПЛОДОВЫХ ОБОЛОЧЕК ОВСА ДЛЯ ПОЛУЧЕНИЯ БИОЭТАНОЛА - ПРЕКУРСОРА ЭТИЛЕНА}

[3-4]. Процессы, основанные на отводе продуктов осахаривания, позволяют повысить начальную концентрацию субстрата и получить более высокий выход конечных продуктов. Преимуществами реализации данного процесса являются: отсутствие потребности в дополнительном оборудовании для осахаривания и сбраживания полученных сахаров в биоэтанол, сокращение продолжительности технологических стадий, и соответственно, снижение капитальных затрат, а также исключение контаминации посторонней микрофрлорой [5].

Биоэтанол из ПОО, полученный в производственных условиях, может быть использован в качестве прекурсора для получения этилена [6]. Этилен является основным продуктом для многих применений в нефттехимической промышленности. Он используется в качестве промежуточного продукта для получения ценных химических веществ, в основном этиленоксида и полимеров, таких как полиэтилен, полиэтилентерефрталат и поливинилхлорид. Ранее нами были проведены исследования по получению биоэтанола из плодовых оболочек овса, обработанных в одну стадию разбавленным раствором гидроксида натрия. Далее сотрудниками ИК СО РАН были проведены экспериментальные исследования синтеза этилена путем каталитической дегидратации биоэтанола из плодовых оболочек овса [7]. В ходе исследований было обнаружено снижение активности алюмооксидного катализатора, это может быть связано с воздействием неорганических микропримесей, оставшихся в биоэтаноле, либо с наличием ионов натрия после стадии предварительной химической обработки сырья. Для исключения этой возможной причины снижения активности катализатора, целью данной работы являлось получение биоэтанола в условиях опытно-промышленного производства из плодовых оболочек овса, обработанных в одну стадию разбавленным раствором азотной кислоты.

\section{ЭКСПЕРИМЕНТАЛЬНАЯ ЧАСТЬ}

В качестве субстрата для стадии осахаривания использовался образец продукта азотнокислой обработки (ПАО), полученный согласно нормативной документации обработкой ПОО 4 \%-ным раствором азотной кислоты в промышленных условиях ИПХЭТ СО РАН в емкостном оборудовании при атмосферном давлении. Обработанные ПОО отжимались от раствора кислоты на фильтр-прессе для отделения варочного раствора от твердого остатка. Отжатый твердый остаток (ПАО) промывался водой до нейтральной реакции. Определение основных характеристик субстратов (массовой доли (м.д.) целлюлозы по Кюршнеру, м.д. пентозанов, м.д. кислотонерастворимого лигнина, м.д. золы) проводили по стандартным методикам [8].

Технологические стадии осахаривания и сбраживания осуществлялись совмещенно. Для стадии осахаривания использовались промышленно доступные ферментные препараты (ФП) в следующей дозировке: 0,04 кг ФП/кг субстрата (ФП «Целлолюкс-А»), 0,02 л ФП/кг субстрата (ФП «Брюзайм BGX»). ФП «Целлолюкс-А» (производитель ООО ПО «Сиббиофрарм», г. Бердск) и «Брюзайм BGX» (поставщик компания «Русфрермент», Г. Москва). В соответствии с аналитическими паспортами ФП стандартизованы по целлюлазной и ксиланазной активности.

Сбраживание осуществляли с использованием дрожжей Saccharomyces cerevisiae Y-1693 Всероссийской коллекции промышленных микроорганизмов (г. Москва). Доза инокулята составила $12 \%$. Сбраживание проводили в анаэробных условиях при $28^{\circ} \mathrm{C}$. Общую численность дрожжей определяли с использованием камеры Горяева. Инокулят подготовлен следующим образом: чистая культура была пересеяна на среду неохмеленного солодового сусла в количестве 5 \% к объему среды, культивирование проводилось 24 ч при температуре $28^{\circ} \mathrm{C}$; затем эти дрожжи в количестве $5 \%$ были перенесены на среду, состоящую из ферментативного гидролизата и неохмеленного солодового сусла в соотношении 1:1, культивирование проводилось 24 ч при температуре $28^{\circ} \mathrm{C}$. Полученные дрожжи в дозировке 12 \% внесены как инокулят в ферментативный гидролизат на опытном производстве, общее количество клеток составило 114,5 млн. КОЕ/мл, из них почкующихся - 20,9\%.

Концентрацию редуцирующих веществ (PB) в пересчете на глюкозу в гидролизате определяли спектрофоотометрическим методом с использованием реактива на основе 3,5динитросалициловой кислоты (Panreac, Испания) на «UNICO UV-2804» (США); относительная погрешность метода составляет $3,45 \%$.

Выход РВ рассчитан с учетом коэффрициента 0,9 , обусловленного присоединением молекулы воды к ангидроглюкозным остаткам соответствующих мономерных звеньев в результате ферментативного гидролиза.

В дистилляте, полученном перегонкой спирта из бражки, ареометром определялась объемная доля спирта согласно ГОСТ Р 
О.В. БАЙБАКОВА, Е.А. СКИБА, И.Н. ПАВЛОВ, В.В. БУДАЕВА, Ю.А. КРЮКОВ,

В.Н. ЗОЛОТУХИН, Е.И. КАЩЕЕВА, Ю.А. ГИСМАТУЛИНА, Г.Ф. МИРОНОВА, Е.К. ГЛАДЫШЕВА, А.А. КОРЧАГИНА, Г.В. САКОВИЧ

51135-2003 [9]. Этанол из бражки сконцентрирован методом простой перегонки и дополнительной очистке не подвергался. Анализ этанола выполнен методом газожидкостной хроматографии (ГЖХ) по ГОСТ Р 51786-2001 [10] на газовом хроматографе с пламенно-ионизационным детектором «Кристалл - 2000М» формы «СКБ Хроматэк», г. Йошкар-Ола, Россия.

Работа выполнена при использовании оборудования Бийского регионального центра коллективного пользования СО РАН (ИПХЭТ СО РАН, г. Бийск).

\section{ОБСУЖДЕНИЕ РЕЗУЛЬТАТОВ}

На основании лабораторных исследований [11-12] разработана и предложена аппаратурно-технологическая схема получения биоэтанола из недревесного целлюлозосодержащего сырья в условиях опытно-промышленного производства. Разработанная технология получения биоэтанола из продукта азотнокислой обработки плодовых оболочек овса внедрена в производственных условиях ИПХЭТ СО РАН. Масштабирование процесса получения биоэтанола проводилось согласно действующей нормативной документации.

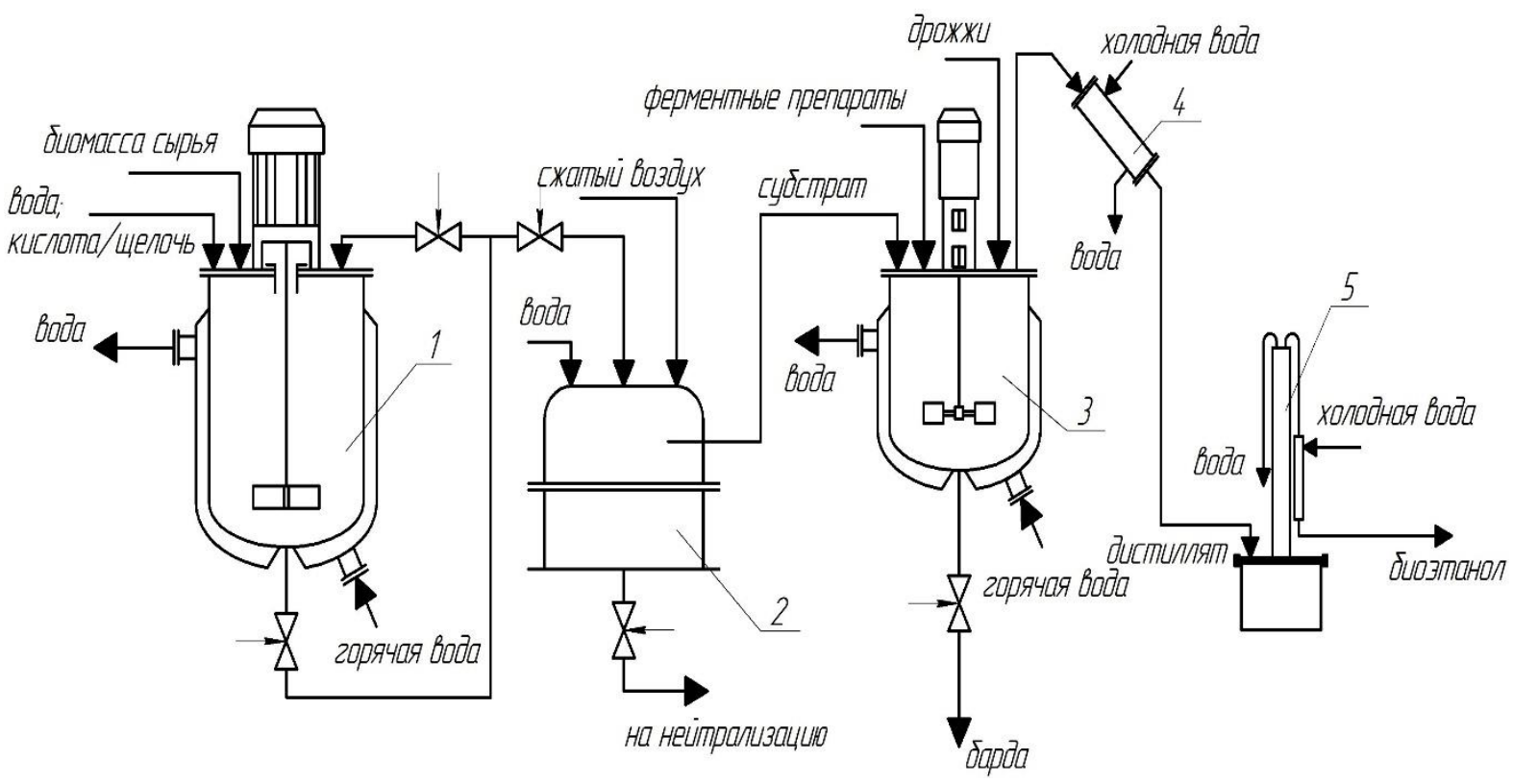

1 - аппарат с перемешивающим устройством; 2 - вакуумный фильтр;

3 - аппарат для осахаривания и сбраживания; 4 - холодильник; 5 - бражная колонна

Рисунок 1 - Аппаратурно-технологическая схема получения биоэтанола из недревесного целлюлозосодержащего сырья

В аппарате 1 объемом 250 л проводилась одностадийная предварительная химическая обработка плодовых оболочек овса. Полученный субстрат (продукт азотнокислой обработки) промывался до нейтральной реакции промывной воды на вакуум фильтре 2. Стадия осахаривания проводилась в аппарате 3 объемом 63 л, в течение 24 ч, при этом осуществлялся круглосуточный контроль активной кислотности и концентрации редуцирующих веществ. После накопления РВ не менее $50 \%$ от массы субстрата проводилось сбраживание осахаренного субстрата без фильтрации непосредственно в аппарате 3. Продолжительность процесса сбраживания составляла
72 ч. Для выделения биоэтанола из бражки в холодильник 4 подавалась холодная вода, содержимое аппарата 3 нагревалось при перемешивании. Биоэтанол конденсировался в холодильнике 4 , поступал в бражную колонну 5 (GS-2, производство компании «Гоним спирт», г. Щелково) для фракционного разделения.

Химический состав плодовых оболочек овса до и после предварительной химической обработки представлен в таблице 1.

Химическая предварительная обработка ПОО в одну стадию разбавленным раствором азотной кислоты в условиях опытно-промышленного производства позволяет повысить содержание гидролизуемых компонентов в 1,2 


\section{ОДНОСТАДИЙНАЯ ОБРАБОТКА ПЛОДОВЫХ ОБОЛОЧЕК ОВСА ДЛЯ ПОЛУЧЕНИЯ БИОЭТАНОЛА - ПРЕКУРСОРА ЭТИЛЕНА}

раза $((88,4 \pm 0,3) \%)$ по сравнению с нативным сырьем $((75,5 \pm 0,3) \%)$, однако доля негидролизуемой части довольно высока: массовая доля лигнина - $(9,2 \pm 0,1) \%$, золы - $(8,2 \pm 0,1) \%$.

Таблица 1 - Химический состав плодовых оболочек овса (ПОО) и продукта их азотнокислой обработки (ПАО ПОО)

\begin{tabular}{|l|c|c|}
\hline \multirow{2}{*}{$\begin{array}{c}\text { Характеристики } \\
\text { субстрата }\end{array}$} & \multicolumn{2}{|c|}{$\begin{array}{c}\text { М.д., \% в пересчете на } \\
\text { а.с.с. }\end{array}$} \\
\cline { 2 - 3 } & ПОО & ПАО ПОО \\
\hline $\begin{array}{l}\text { Целлюлоза } \\
\text { по Кюршнеру }\end{array}$ & $44,9 \pm 0,2$ & $79,2 \pm 0,3$ \\
\hline Пентозаны & $30,6 \pm 0,2$ & $9,2 \pm 0,1$ \\
\hline Лигнин & $17,9 \pm 0,1$ & $13,8 \pm 0,1$ \\
\hline Зола & $4,8 \pm 0,1$ & $8,2 \pm 0,1$ \\
\hline $\begin{array}{l}\text { Сумма гидро- } \\
\text { лизуемых } \\
\text { компонентов }\end{array}$ & $75,5 \pm 0,3$ & $88,4 \pm 0,3$ \\
\hline
\end{tabular}

При этом важно отметить, что нерастворимый лигнин, массовое содержание которого достаточно значительно, не оказывает негативного влияния на процессы осахаривания и сбраживания. Продукт азотнокислой обработки представляет собой многокомпонентную смесь, включающую различные примеси, в том числе растворимые продукты окислительного нитрования лигнина, которые могут ингибировать осахаривание [7, 13]. Поэтому крайне важной является стадия отмывки субстрата от растворимого лигнина: критерием качества отмывки является не $\mathrm{pH}$ промывных вод до нейтральной реакции, а отсутствие их окраски, что достигается значительно сложнеe.

В процессе осахаривания концентрация редуцирующих веществ увеличивалась экспоненциально и через 24 ч от начала процесса осахаривания составила $(44 \pm 0,2)$ г/л, что соответствует выходу $(66 \pm 0,3)$ г/л от концентрации субстрата. После 24 ч от начала процесса осахаривания (реакционная масса охлаждалась до $28^{\circ} \mathrm{C}$ ) в осахаренный субстрат вносился инокулят дрожжей. Морфофизиологический анализ состояния клеток дрожжей в процессе спиртового брожения позволяет сделать вывод о том, что осахаренный субстрат продукта азотнокислой обработки ПОО не является полноценной питательной средой для их развития. Общее количество клеток снижалось от 114,5 млн. КОЕ/мл до 10,7 и 10,9 млн. КОЕ/мл через 48 ч и 64 ч соответственно, что не соответствует нормам спиртовой промышленности (количество дрожжевых клеток должно быть не менее 80-100 млн. КОЕ/мл [14]), од- нако может быть объяснено значительной абсорбцией клеток на остатках негидролизованного субстрата. При проведении совмещенного процесса осахаривания и сбраживания в условиях опытно-промышленного производства в среде были обнаружены посторонние микроорганизмы (микрококки), поэтому был внесен антибиотик «Цефотаксим».

Накопление биоэтанола сопряжено с потреблением субстрата, через 36 ч от начала процесса крепость бражки составила 0,4 об. \%, далее увеличивалась экспоненциально и к концу брожения составила 2,3 об. \%. Таким образом, установлено, что в производственных условиях получен биоэтанол с выходом $(53,5 \pm 0,3)$ \% от концентрации субстрата, или от массы сырья с выходом $(17,9 \pm 0,1)$ дал/т.

Методом газожидкостной хроматографии выявлено, что опытный образец биоэтанола из продукта азотноксилой обработки плодовых оболочек овса после ректификации по массовой концентрации альдегидов, эфиров и содержанию метанола соответствует спирту высшей очистки из пищевого сырья. Концентрация альдегидов после ректификации в 50 раз ниже регламентируемой для спирта технического марки А (200 мг/дм³), эфиров - в 80 раз (80 мг/дм³), содержание метанола - 0,011 об. \%, что свидетельствует о получении биоэтанола высокого качества.

Для проверки пригодности полученных образцов биоэтанола к каталитической дегидратации в этилен, они были переданы в ИК СО РАН им. Г.К. Борескова.

\section{ВЫВоды}

В производственных условиях в оборудовании объемом 250 л был путем одностадийной обработки был получен субстрат - продукт азотнокислой обработки из плодовых оболочек овса. Химический состав субстрата в основном представлен гидролизуемыми компонентами. В емкостном оборудовании объемом 63 л масштабирован совмещенный процесс осахаривания и сбраживания. Выход биоэтанола составил 17,9 дал/т плодовых оболочек овса, при этом биоэтанол характеризуется высоким качеством.

Работа подготовлена при поддержке Комплексной программы фундаментальных научных исследований СО РАН II.1 «Междисциплинарные интеграционные исследования» (проект № 0385-2018-0013). 


\section{СПИСОК ЛИТЕРАТУРЫ}

1. Aguilar-Reynosa A. Comparison of microwave and conduction-convection heating autohydrolysis pretreatment for bioethanol production [Text] / A. AguilarReynosa, A. Romaní, R.M. Rodríguez-Jasso, C.N. Aguilar, G. Garrote, H.A. Ruiz // Bioresource Technology. - 2017. - Vol. 243. - P. 273-283.

2. Ramos L.P. Enzymatic hydrolysis of steam-exploded sugarcane bagasse using high total solids and low enzyme loadings [Text] / L.P. Ramos, L. da Silva, A.C. Ballem, A.P. Pitarelo, L.M. Chiarello, M.H.L. Silveira // Bioresource Technology. - 2015. - Vol. 175. P. 195-202.

3. Hoyer K. The effect of prehydrolysis and improved mixing on high-solids batch simultaneous saccharification and fermentation of spruce to ethanol [Text] / K. Hoyer, M. Galbe, G. Zacchi // Process Biochemistry. - 2013. - Vol. 48. - P. 289-293.

4. Rodrigues T.H.S. The bioconversion of pretreated cashew apple bagasse into ethanol by SHF and SSF processes [Text] / T.H.S. Rodrigues, E.M. de Barros, J. de Sá Brígido, W.M. da Silva, M.V.P. Rocha, L.R.B. Gonçalves // Applied Biochemistry and Biotechnology. - 2016. - Vol. 178. - P. 1167-1183.

5. Mesa L. Comparison of process configurations for ethanol production from two-step pretreated sugarcane bagasse [Text] / L. Mesa, E. González, I. Romero, E. Ruiz, C. Cara, E. Castro // Chemical Engineering Journal. - 2011. - Vol. 175. - P. 185-191.

6. Kagyrmanova A.P. Catalytic dehydration of bioethanol to ethylene: Pilot-scale studies and process Simulation [Text] / A.P. Kagyrmanova, V.A. Chumachenko, V.N. Korotkikh, V.N. Kashkin, A.S. Noskov // Chemical Engineering Journal. - 2011. - Vol. 176177. - P. 188- 194.

7. Skiba E.A. Pilot Technology Of Ethanol Production From Oat Hulls For Subsequent Conversion To Ethylene / E.A. Skiba, O.V. Baibakova, V.V. Budaeva, I.N. Pavlov, M.S. Vasilishin, E.I. Makarova, G.V. Sakovich, E.V. Ovchinnikova, S.P. Banzaraktsaeva, N.V. Vernikovskaya, V.A. Chumachenko // Chemical Engineering Journal. - 2017. - Vol. 329. - P. 178-186.

8. Оболенская, А.В. Лабораторные работы по химии древесины и целлюлозы [Текст] / А.В. Оболенская, 3.П. Ельницкая, А.А. Леонович. - М.: Экология, 1991. - 320 с.

9. ГОСТ Р 51135-2003. Изделия ликероводочные. Правила приемки и методы анализа. Технические требования. - Введ. 1998-03-02. - М.: ИУС, 2003. - $116 \mathrm{c}$.

10. ГОСТ Р 51786-2001. Водка и спирт этиловый из пищевого сырья. Газохроматографический метод определения подлинности. - М.: Изд-во стандартов, 2001. - 8 с.

11. Skiba E.A. Dilute nitric-acid pretreatment of oat hulls for ethanol production [Text] / E.A. Skiba, V.V. Budaeva, O.V. Baibakova, V.N. Zolotukhin, G.V. Sakovich // Biochemical Engineering Journal. - 2017. Vol. 126. - P. 118-125.

12. Байбакова О.В. Превращение лигноцеллюлозного материала из плодовых оболочек овса в биоэтанол [Текст] / О.В. Байбакова, Е.А. Скиба // Ползуновский вестник. - 2014. - № 3. - С. 181-185.
13. Скиба Е.А. Ферментативный гидролиз лигноцеллюлозных материалов в зависимости от способа их подготовки [Текст] / Е.А. Скиба, Т.О. Момот, Н.В. Бычин, В.Н. Золотухин // Ползуновский вестник. - 2013. - № 3. - С. 197-202.

13. Римарева Л.В. Микробиологический контроль спиртового и ферментного производств [Текст] / Л.В. Римарева. - М.: Россельхозакадемия, 2005. -200 c.

Байбакова Ольга Владимировна, кандидат технических наук, младший научный сотрудник лаборатории биоконверсии, Федеральное государственное бюджетное учреждение науки Институт проблем химико-энергетических технологий Сибирского отделения Российской академии наук (ИПХЭТ СО РАН), olka baibakova@mail.ru, тел. (3854) 30-59-85.

Скиба Екатерина Анатольевна, кандидат технических наук, дочент, старший научный сотрудник лаборатории био-конверсии, Федеральное государственное бюджетное учреждение науки Институт проблем химико-энергетических технологий $\mathrm{Cu}$ бирского отделения Российской академии наук (ИПХЭТ СО РАН), eas08988@mail.ru, тел. (3854) 30-59-85.

Павлов Игорь Николаевич, кандидат технических наук, доцент, старший научный сотрудник лаборатории биоконверсии, Федеральное государственное бюджетное учреждение науки Институт проблем химико-энергетических технологий Сибирского отделения Российской академии наук (ИПХЭТ СО РАН), pawlow-in@mail.ru, тел. (3854) 30-59-85.

Будаева Вера Владимировна, кандидат химических наук, доцент, заведующая лабораторией биоконверсии, Федеральное государственное бюджетное учреждение науки Институт проблем химико-энергетических технологий Сибирского отделения Российской академии наук (ИПХЭТ СО РАН), budaeva@ipcet.ru, тел. (3854) 30-59-85.

Крюков Юрий Андреевич, кандидат технических наук, начальник производства субстанций лекарственных веществ, Федеральное государственное бюджетное учреждение науки Институт проблем химикоэнергетических технологий Сибирского отделения Российской академии наук (ИПХЭТ CO РAH), admin@ipcet.ru, тел. (3854) 30-5985.

Золотухин Владимир Николаевич, кандидат технических наук, старший научный сотрудник лаборатории биоконверсии, Федеральное государственное бюджетное 


\section{ОДНОСТАДИЙНАЯ ОБРАБОТКА ПЛОДОВЫХ ОБОЛОЧЕК ОВСА ДЛЯ ПОЛУЧЕНИЯ БИОЭТАНОЛА - ПРЕКУРСОРА ЭТИЛЕНА}

учреждение науки Институт проблем химико-энергетических технологий Сибирского отделения Российской академии наук (ИПХЭТ СО РАН), admin@ipcet.ru, тел. (3854) 30-59-85.

Кащеева Екатерина Ивановна, кандидат технических наук, старший научный сотрудник лаборатории биоконверсии, Федеральное государственное бюджетное учреждение науки Институт проблем химикоэнергетических технологий Сибирского отделения Российской академии наук (ИПХЭТ CO PAH), massl@mail.ru, тел. (3854) 30-59-85.

Гисматулина Юлия Александровна, кандидат технических наук, научный сотрудник лаборатории биоконверсии, Федеральное государственное бюджетное учреждение науки Институт проблем химикоэнергетических технологий Сибирского отделения Российской академии наук (ИПХЭТ CO РАH), julja.gismatulina@rambler.ru, тел. (3854) 30-59-85.

Миронова Галина Федоровна, инженер лаборатории биоконверсии, Федеральное государственное бюджетное учреждение науки Институт проблем химико-энергетических технологий Сибирского отделения Российской академии наук (ИПХЭТ СО РАН) 659322, Алтайский край, г. Бийск, ул. Социалистическая 1, e-mail: yur galina@mail.ru, тел. (3854) 30-59-85
Гладышева Евгения Константиновна, кандидат технических наук, младший научный сотрудник лаборатории биоконверсии, Федеральное государственное бюджетное учреждение науки Институт проблем химико-энергетических технологий Сибирского отделения Российской академии наук (ИПХЭТ СО РАН), evg-gladysheva@yandex.ru, тел. (3854) 30-59-85.

Корчагина Анна Александровна, кандидат технических наук, младший научный сотрудник лаборатории биоконверсии, Федеральное государственное бюджетное учреждение науки Институт проблем химико-энергетических технологий Сибирского отделения Российской академии наук (ИПХЭТ СО РАН), yakusheva89_21.ru@mail.ru, тел. (3854) 30-59-85.

Сакович Геннадий Викторович, академик РАН, советник РАН, научный руководитель, Федеральное государственное бюджетное учреждение науки Институт проблем химико-энергетических технологий $\mathrm{Cu}$ бирского отделения Российской Академии наук. Адрес: ул. Социалистическая, 1, Бийск, Алтайский край, 659322 (Россия), тел: 8(3854)30-59-55, 30-59-98 e-mail: ipcet@mail.ru, admin@ipcet.ru 